Annals of Warsaw University of Life Sciences - SGGW

Land Reclamation No 39, 2008: 151-158

(Ann. Warsaw Univ. of Life Sci. - SGGW, Land Reclam. 39, 2008)

\title{
Simplified technique for the determination of soil aggregation in assessing the resistance of soils to erosion and deflation
}

\author{
VIKTOR GRIGORIEV ${ }^{1}$, LESZEK PIECHNIK ${ }^{2}$, \\ STANISŁAW PODSIADŁOWSKI ${ }^{2}$ \\ ${ }^{1}$ Lomonosov Moscow State University, Russian Federation \\ ${ }^{2}$ Poznań University of Life Sciences, Poland
}

\begin{abstract}
Simplified technique for the determination of soil aggregation in assessing the resistance of soils to erosion and deflation. The technique provides for the determination of the size and percentage of aggregates of the coarse fraction on the surface of a friable soil followed by the determination of the aggregation index to be used in assessing spatial and temporal resistance of soil to erosion and deflation. The uses of this technique make routine sampling and aggregate analysis after Savvinov unnecessary. Its some outcomes for soils of Poland are given.
\end{abstract}

Key words: soil erosion prediction, aggregate structure of soil.

\section{INTRODUCTION}

Physical entities of both phenomena, i.e., the resistance of soil to water erosion and deflation, regarded as being essentially similar, as their quantitative indexes depend on the same soil characterizes The resistance to water erosion and to deflation is assessed using critical velocities of water air flows corresponding to the beginning of the detachment and transport of soil particles (aggregates).

\section{MATERIAL AND METHODS}

Basing on a theoretical analysis of quantitative relationships between critical water flow $\left(V_{d p}\right)$ flow $\left(V_{m}\right)$ velocities (the threshold shear velocity), on one hand, and other soil properties, on the equations for the determination of $V_{d p}$ and $V_{m}$ were derived (these equations are close with respect to structure) (Kuznetsov 1981, Kuznetsov and Glazunov 2004). The main variables are the size of soil particles (or detached by the water or air flows and cohesion between them).

For firable plow soil horizons, which at a density $\left(\rho_{v}\right)$ below $1.25 \mathrm{~g} \cdot \mathrm{cm}^{-3}$ have actually no cohesion aggregates, the formulas for $V_{d p}$ and $V_{m}$ become much simpler, with aggregation indexes as main determined by a routine sieve method after Savvinov (Vadyunina and Korchagina 1973, Kuznetsov and Glazunov 2004):

$$
\begin{aligned}
& V_{d p}=1.55 \sqrt{\frac{g}{n^{\prime} \rho_{0}}(1-P) d\left(\rho-\rho_{0}\right)} \\
& V_{m}=2.40 \sqrt{l_{60} \frac{\rho_{a}-\rho_{B}}{\rho_{B}} g}
\end{aligned}
$$

where:

$V_{d p}$ - bottom (at height of projections of grain $\Delta(\Delta=0.7 d)$ washing away, velocity, $\mathrm{m} \cdot \mathrm{s}^{-1}$;

$g-$ an acceleration of a gravity, $\mathrm{m} \cdot \mathrm{s}^{-1}$; 
$n^{\prime}$ - the quotient of an overload which is taking into account a level of a pulsation of velocities in the flow; $\rho_{o}$ - accordingly a denseness of a solid phase of soil and water, $\mathrm{t} \cdot \mathrm{m}^{-3}$;

$P-$ a porosity of units in lobes from unity;

$d$ - weighted-mean diameter of water-stable aggregates at wet sifting (on

N.I. Savvinov's method), m;

$V_{m}$ - the velocity of a wind conforming to the beginning of a mass movement of particles at height $1 \mathrm{sm}$ from a surface of soil, $\mathrm{m} \cdot \mathrm{s}^{-1}$;

$l_{60}$ - the weighted-mean dimension of the fine units amounting $60 \%$ from an aggregate composition of soil at its dry sifting, $\mathrm{m}$;

$\rho_{a}-$ a denseness of units, $\mathrm{t} \cdot \mathrm{m}^{-3}$;

$\rho_{b}-$ a denseness of air at temperature $t$, $\mathrm{t} \cdot \mathrm{m}^{-3}$.

In the formula for the calculation of $V_{p}$ - values mean weighted diameter of water stable aggregates $(d)$ was used due to complexity and irregularity of particle size distribution. This value is computed basing on the results of wet sieving using the following equation:

$$
\bar{d}=\frac{\sum_{i=1}^{n} d_{i} P_{i}}{100}
$$

where:

$d_{i}$ - mean diameter;

$P_{i}$ - a percentage of water stable aggregates of the $i$-fraction.

All fractions, including aggregates which can be passed through the finest sieve, are summed up. To compute the critical air velocity $V_{m}$ ("initial fluid threshold" or the first deflation) mean weighted diameter $l_{60}$ is computed basing on the dry sieving data; this group comprises aggregates with the diameter not exceeding a certain value accounting for $60 \%$ as determined from the cumulative aggregate (Kuznetsov et al. 1986). The mean weighted diameter $l_{60}$ is given by the equation:

$$
l_{60}=\frac{\sum_{i=1}^{n} l_{i} P_{i}}{60}
$$

where:

$l_{\mathrm{i}}$ - mean diameter,

$P_{i}$ - a percentage of aggregates of the $i$-fraction.

Both indexes describe particle size distribution pattern, and there is a high correlation between there indexes and the $V_{p}$ and $V_{m}$ values $\left(V_{p}=K_{1} \sqrt{d}, V_{m}=K_{2} \sqrt{l_{60}}\right)$. The parameters $K_{1}$ and $K_{2}$ are main by functions of aggregate density varying within a narrow range for various soils.

At the same time, soil aggregation being basic to the computation of $d$ and $l_{60}$, is characterized by a considerable spatial variability caused not only by soil genetic characteristics, but also by destructive forces resulting from recurrent drying, moistening, rainfall, treatments, etc. Therefore, to facilitate soil mapping basing on the resistance of these soils to erosion and deflation as well as to calculate erosion control measures, mass soil aggregation analyses are necessary. Simple as it is, Savvinov's method not always provides for the necessary results, as it is labor consuming and calls for special equipment to be used. Besides that, requirements specified as to the conditions of the analysis (especially dry sieving technique) cannot be always satisfied in practice. For example, dry sieving is to be carried out at natural soil 
moisture level, but at the same time the samples are to be dry enough to be handled properly. In sampling and transporting soil samples, especially those with low mechanical stability, care must be taken not to destroy natural aggregates (Voronin 1986).

If the above requirements are not satisfied, serious errors are possible in calculating $\bar{d}$ and $l_{60}$ resulting in subsequent errors in calculating $V_{p}$ and $V_{m}$. In this connection, the development of simplified methods of the assessment of $d$ and /60 values to obtain reliable information on their spatial and temporal variability, is quite an urgent problem being an objective of our studies; $\bar{d}$ - value resulting from wet sieving depends to a considerable extent on the rate of the initial soil moistening. Positive effect of initial capillary moistening on the water stability of the soil structure was mentioned repeatedly in the literature. This phenomenon is accounted for by gradual replacement of adsorbed air and the air which could potentially be entrapped, as well as by cohesion being better pronounced in the course of slow capillary moistening. For example, in moistening soil samples on a fine ceramic filter in vacuum an ideal water stability of aggregates can be obtained when $d$ becomes close to a level obtained using the dry sieving technique $(\bar{D})$.

Therefore, to obtain a boundary $\bar{d}$ - value Savvinov's technique (the aggregate analysis) for air-dry and capillarymoistened soil samples is recommended. To provide for standard imitation of initial soil moistening under real conditions (due to rainfall, snow melting, and irrigation) a simplified technique is proposed. Air-dry samples were capillary moistened on filter gauze or filter paper for 10-12 hours (their ends immersed in water). The distance between the water surface and the sample was 5 to $7 \mathrm{~cm}$.

Numerous determinations of boundary $\bar{d}$ - values showed the range of their variations to depend considerably on the initial aggregation (Grigoriev and Kuznetsov 1986; Kuznetsov et al. 1990). Soil aggregation is estimated basing on the mean weighted diameter of aggregates (crumbs) $D$ calculated from Eq. (1) and dry-sieving results. Such effect of crumbliness on the size of water-stable aggregates is accounted for by the fact that the rate of the destruction of aggregates depends on the rate of the penetration of water into the soil crumbs: the larger the crumbs, the lower the rate of their moistening and consequently, the less the destruction. This pattern is most clearly pronounced in initially capillary-moistened samples.

Raindrops were shown to have a pronounced effect on the ( $f$-values). The raindrop impact causes first of all the destruction of the largest but less water stable crumbs, resulting in a decrease of soil crumbliness and decrease of the size of water stable aggregates.

Consequently, there exists a relationship between the dynamic soil characteristics $\bar{d}$ and $\bar{D}$. This relationship can be described by a simple empirical equation:

$$
\bar{d}=\alpha \bar{D}^{\beta}
$$

The magnitudes of empirical coefficients and depending on cohesion forces and initial soil moistening can be determined experimentally. Their approximated values for air-dry $\left(W_{r}\right)$ and capillary-moistened $\left(W_{k}\right)$ soils are given in the literature (Kuznetsov et al. 1990). 
For brown wood sandy loam soils of Poland quotients $\alpha$ and $\beta$ according to their humidity are equal: at $W=W_{r}$, 0.18 and $0.74 ; W=W_{k}, 0.50$ and 0.74 (Grigoriev et al. 1993).

For the count of influence of initial humidity (W) on magnitude $d$ the following dependence (Bobkov and Grigoriev 2001) fixed:

$$
d=\left(d_{o}-d_{r}\right)\left[\left(w-w_{r}\right) /\left(w_{k}-w_{r}\right)\right]^{1.7}+d_{r}
$$

where:

$d_{r}, d_{o}$ are, accordingly, weighted-mean diameter of water-stable aggregates at moisture-retentive humidity $\left(W_{r}\right)$ and a capillary moisture capacity.

More complex is the equation describing the relationship between $l_{60}$ and $\bar{D}$. Studies of the aggregation of various soil types with various particle size distribution patterns (as chernozems of the Ukraine, Moldova, North Caucasus, brown forest soils of Krasnodar territory, light chestnut soils of Volgograd region, sierozems of Central Asia) showed the structural characteristics $\left(l_{60}\right)$ to depend considerably on the variability of aggregation described by the ratio $\bar{D} / \bar{D}_{\max }$. This relationship is described by the equation:

$$
l_{60}=K\left(\bar{D} / \bar{D}_{\max }\right)^{2}
$$

where

$\bar{D}_{\max }-$ the mean diameter of the coarse crumb (aggregates) accounting for not more than 5\% when using the dry-sieving technique;

$K \quad$ - an empirical coefficient depending on the soil characteristics.

For sands and loamy sands with low aggregate porosity $K=10$; for to loamy soils with the most favorable porosity of aggregates at $K=25$. For other soils the $K$ - value is equal to 15 . The presence of one and the same parameter $\bar{D}$ in both equations makes it possible to simplify the structural soil characteristics $\bar{d}$ and $l_{60}$. The $\bar{D}-$ value is a mean weighted diameter of aggregates determined by the numerical integration of the aggregate distribution function. Therefore, one of the possible ways of the simplification is to find a simpler way of determination of $\bar{D}$ - values basing on the relationships between $\bar{D}$ and individual fractions. The closest relationship was shown to exist between $\bar{D}$ and the content of the coarsest fraction of aggregates. This relationship is described by the equation:

$$
\bar{D}=0.285\left(P_{\max } \bar{D}_{\max } /\right)^{0.57}
$$

where:

$\bar{D}$ - the mean weighted diameter of aggregates as determined by the dry-sieving technique, $\mathrm{mm}$;

$P_{\max }, \bar{D}_{\text {max }}$ are a percentage and the size of the coarsest fraction of soil aggregates, $\mathrm{mm} ; \bar{\rho}_{a}$ is the mean weighted density of aggregates, $\mathrm{g} \cdot \mathrm{cm}^{-3}$.

Usually $\bar{\rho}_{a}$ is determined experimentally. It can be approximated using an equation resulted from the integration of the relationship between the porosity and size of aggregates (Kuznetsov et al. 1988):

$$
\begin{aligned}
& \bar{\rho}_{a}=\rho_{\max }-K_{s}\left(\rho-\rho_{\max }\right) \cdot \\
& \cdot \ln \left[K_{s} /\left(\bar{D}_{\max }+K_{s}\right)\right] / \bar{D}_{\max }
\end{aligned}
$$

where:

$\rho-$ the density of the solid phase, $\mathrm{g} \cdot \mathrm{cm}^{-3}$; 
$\rho_{\max }-$ the density of the coarsest aggregates, $\mathrm{g} \cdot \mathrm{cm}^{-3}$;

$\bar{D}_{\max }$ - the size of the coarsest fraction of aggregates, $\mathrm{mm}$;

$K_{s} \quad$ - an empirical coefficient depending on the soil $\mathrm{j}$ characteristics. The value of this coefficient varies from 0.1 to 0.3 .

\section{DISCCUSSION}

Tentative computations using Eq. (9) showed that at $K_{s}=0.2$ for soils with the porosity of coarse aggregates 30,40 , and $50 \%$, their size varying from 10 to $3 \mathrm{~mm}$, the mean weighted density changed within the ranges $1.9-2.1,1.7-1.8$, and $1.4-1.6 \mathrm{~g} \cdot \mathrm{cm}^{-3}$, respectively. Obviously, in doing tentative computations the following mean density values can be assumed: for light-textured soils with low aggregate porosity and pulverous structure the mean density value is $2.0 \mathrm{~g} \cdot \mathrm{cm}^{-3}$; for loamy soils with the most favorable porosity of aggregates, $1.5 \mathrm{~g} \cdot \mathrm{cm}^{-3}$; for loamy soils with other type of porosity, $1.7 \mathrm{~g} \cdot \mathrm{cm}^{-3}$.

To verify the derived relationships, the data obtained by Voronin (1986) as well as the results of our studies which had not been used in deriving Eq. (7) and (8) were used. Computed $l_{60}$ and $\bar{D}$ values were in line with the empirical results. As a result, it has been shown that empirical relationships can be used for speedy determination of aggregation indexes characterizing resistance of soils to water erosion and deflation. To this end, quite sufficient is the determination of the content and size of the coarsest fraction on the soil surface. Several methods of counting are employed. Planimetric method is the most convenient; various versions of this method can be employed, such as the methods of squares, sketching, photographing. However, each method needs adjustment and calibration.

For instance, by direct measuring the dimensions and counting the number of coarse aggregates per unit area of the soil surface it has been established that the coarse fraction content as determined by the sieving technique $\left(P_{\max }\right)$ is equal to 0.8 of the area measured $\left(P_{\max }\right)$. Consequently, this value can be used as an adjustment coefficient: $P_{\max }=0.8 P_{\max }^{\prime}$.

After the determination of the size and percentage of the coarse fraction using Eq. (7) and (8), $l_{60}$ and $\bar{D}$ are computed. Then from Eq. (5) describing the relationship between the size of water stable aggregates and crumbliness of the soil the value $\bar{d}$ is determined. Then from the equations (1), (2) for the critical water flow velocity and initial fluid threshold (critical air velocity) the resisitance of soils to water and wind erosion is assessed using $l_{60}$ and $\bar{d}$.

The simplicity of the proposed method for the determination of $\bar{d}$ and $l_{60}$. provides for a large-scale assessment of critical water and air flow velocities to be used in designing erosion control measures with spatial and temporal variability of the resistance of soils to water and wind erosion being taken into account.

For the fine-grained light and sprayed heavy soils having average diameter water-strong, units $(\bar{d})$ less than $0.25 \mathrm{~mm}$ and diameter of structural separateness $(\bar{D})$ less than $0.5 \mathrm{~mm}$, calculated magnitudes $V_{\partial p}$ and $V_{m}$ under formulas (1) and (2) less than their experimentally established values. With reduction $\bar{d}$ and 
$\bar{D}$ this distinction increases (Bobkov and Grigoriev 2001).

Raise $V_{\partial p}$ and $V_{m}$ for fine-grained and sprayed soils and grounds is connected to appearance of adhesive powers between particles. It fixed, that magnitude $V_{\partial p}$ designed for sprayed and feeble - aggregated soils under the formula (1), it is necessary to increase in $z_{1}$ time:

$$
z_{1}=\left(7.3 \cdot 10^{-12} / d^{3}+1\right)^{0.5}
$$

Calculated values $V_{m}$ under the formula (2) - in $z_{2}$ time:

$$
z_{2}=\left[\left(4 \cdot 10^{-3} /\left(\rho_{a} \bar{D}\right)\right]^{0.5} \text { at } \bar{D}<0.008 \mathrm{~m}\right.
$$

Use $z_{1}$ and $z_{2}$ allows to increase a scope of observational - theoretical formulas (1), (2) and to increase exactitude of calculations $V_{d p}$ and $V_{m}$. For approximate definition $V_{d p}$ and $V_{m}$ it is convenient to use prime empirical equations:

$$
\begin{aligned}
& V_{d p}=A_{1} P_{\max }^{0.22} D_{\max }^{0.22} \rho_{a}^{0.28} ; \\
& A_{1}=8.6 \cdot 10^{-2} z_{1} \sqrt{\alpha / n^{\prime}} \\
& V_{m}=A_{2} P_{\max }^{0.57} D_{\max }^{-0.43} \rho_{a}^{-1.73} ; \quad A_{2}=15.2 z_{2}
\end{aligned}
$$

where $\alpha$ is quotient in the formula (5).

For condensed or the bound radicals of plants of horizons of actual soils of the formula for determination $V_{\partial p}$ and $V_{m}$ should keep the arguments which are taking into account a compendency of soils.

$$
V_{d p}=1.55 \sqrt{\frac{g}{n^{\prime}}\left[\left(\rho-\rho_{0}\right) \bar{d}(1-P)+1.25 C_{y}^{H}\right]}
$$

The fatigue resistance on a breakage $\left(C_{y}^{H}\right.$, $\left.\mathrm{t} / \mathrm{m}^{2}\right)$ is established by results of definition of common coupling by a method of a scour of soil by a water jet $\left(C_{g s}, \mathrm{t} \cdot \mathrm{m}^{-2}\right)$ :

$$
C_{y}^{H}=0.31\left(K C_{g s}\right)^{2.25}
$$

where $K$ is quotient of a homogeneity of coupling of soil $(K \sim 0.5)$.

It fixed, that in soils with the small content of radicals (R) satisfactory connection of coupling, specific by a hydro jet method, with quotient of a porosity $\left(\varepsilon=\rho / \rho_{v}-1\right)$ and by a limit inferior of a plasticity $\left(W_{n g p} \cong 0.42 C_{g s}\right)$ is observed:

$$
C_{g s}=2.5 \cdot 10^{-6} W_{n g p}^{3.6} / \varepsilon^{3}
$$

where $C_{g s}$ is the content of particles (diameter less than $0.01 \mathrm{~mm}$ ) in grain-size structure of soil, $\%$.

Special researches of soils samples with the different weight content of roots in diameter less than $1 \mathrm{~mm}(\mathrm{R})$ from 0

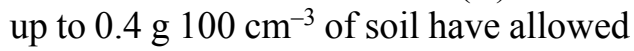
receiving the formula for calculation of magnitude of common coupling soil with the count of influence of root systems of plants:

$$
\begin{aligned}
& C_{g s}=2.5 \cdot 10^{-6} \cdot \\
& \cdot(1+0.025 \exp (14.0 \mathrm{R})) W_{n g p}^{3.6} / \varepsilon^{3}
\end{aligned}
$$

At the given stage there are empirical values of quotient $n$ ' by comparison of values calculated and fixed experimentally and washing away velocities for the basic types of slopes streams. In outcome the following approximate values fixed: for streams at lack of influence of a rain and $n^{\prime}=2.3$; for the rain torrents $n_{\partial}^{\prime}=4$ (Grigoriev et al. 1993; Grigoriev et al. 1996; Kuznetsov et al. 1988) 
Concrete values $n$ ' can be obtained by calculated way on empirical dependences. For torrents at lack of influence of the rain a dropping magnitude $n^{\prime}$ is determined in dependence on diameter of particles $(\bar{d})$ :

$$
n^{\prime}=1+\frac{\bar{d}}{0.00005+0.3 \bar{d}}
$$

Dependence can be applied for calculation $n_{\partial}^{\prime}$ (Kuznetsov et al. 1988):

$$
n_{\partial}^{\prime}=n^{\prime}\left[1+0.28 r\left(V_{k}^{2} / V_{k p}^{2}-1\right)\right]
$$

where:

$n^{\prime}$ - the quotient describing a pulsation of velocities in a water flow without a rain $\left(n^{\prime}=2.3\right)$;

$V_{k p}$ - critical roiling velocity of fall of the rain a dropping for soils, $\mathrm{m} / \mathrm{s}$.

Magnitude $V_{k p}$ for friable plough layers of soils can be fixed under the formula:

$$
V_{k p}=1.8 \cdot 10^{2} n_{0}^{1.2} \cdot d_{\partial}^{0.2} / J^{0.6}
$$

where $V_{k p}$ in $\mathrm{m} / \mathrm{s}$ and $d_{\partial}$ in $\mathrm{m} . J$ is a slope of a surface $d_{\partial} \cong d$.

Magnitude $n_{0}$, at lack in channels of aboriginal hydraulic resistances is determined by the dimension of particles $(d)$, composing a bottom of the flow (Kuznetsov et al. 1988):

$$
n_{0}=0.05 \Delta^{0.17}
$$

where $\Delta$ is height of projections of a grain $(\Delta=0,7 d), \mathrm{m}$.

Speed of fall of the rain a dropping $\left(V_{k}\right)$ and their dimension $\left(d_{k}\right)$ for natural rains are defined by calculated way but to prime formulas (Kuznetsov et al. 1988):

$$
\begin{aligned}
& V_{k}=4.11 \sqrt{d_{k}} ; \quad d_{k}=2.48 r^{0.2} ; \\
& V_{k}=6.47 r^{0.1}
\end{aligned}
$$

where $r$ is intensity of a rain, $\mathrm{mm}$ minutes $^{-1}$.

At rains of major intensity intensive destruction of lumps of soil is observed, especially at its initial air-dry condition, and together with it reduction of the dimension of water-stable aggregates. Magnitude $\bar{d}$ approachs the value fixed at the analysis of an aggregate composition on Savvinov's method for air-dry soil $\left(\bar{d} \cong \bar{d}_{\mathrm{r}}\right)$. At rains of small intensity the dry soil is humidified slowly, is capillary, and consequently magnitude $\bar{d}$ of the upper layer of soil approaches the value fixed at the analysis beforehand is capillary - humidified $\operatorname{soils}\left(\bar{d} \cong \bar{d}_{0}\right)$.

The explained calculated technique in part has been used by development and practical realization of models of an assessment of a rainfall runoff, erosional-preventive (anti-deflation) resistance and a rain erosion of soils in traces of farm machines in terrain of an experimental station "Wierzenica" near Poznań (Poland) (Grigoriev et al. 1993; Grigoriev et al. 1996). The approximate assessment of influence of various farm implements on erosional-preventive $\left(V_{\partial p}\right)$ and anti-deflation $(\mathrm{Vm})$ resistance of sandy-loam and sandy loam brown forest soils of Poland possessing negligible coupling between units $\left(C_{y}^{H}\right)$, will be carried out on their change lumpiness $(\bar{D})$ :

$$
\begin{aligned}
& V_{\partial p_{1}} / V_{\partial p_{2}} \cong\left(\bar{D}_{1} / \bar{D}_{2}\right)^{0.37} ; \\
& V_{m_{1}} / V_{m_{2}} \cong\left(\bar{D}_{1} / \bar{D}_{2}\right)^{0.5}
\end{aligned}
$$

where 1, 2 are indexes of values accordingly before and after a soil cultivation. 
Magnitudes of weighted-mean diameter of lumps of soil $\left(\bar{D}_{1}, \bar{D}_{2}\right)$ calculate on the equation (8), which arguments $\left(P_{\max }\right.$, $\bar{D}_{\max }, \bar{\rho}_{a}$ ) easily define on the explained technique. Ratios (23) use at an operative expert choice of mechanisms, optimum variants of processing of soils and technology of its carrying out, providing high parameters of their resistance to erosion and a deflation.

\section{REFERENCES}

1. BOBKOVA.V.,GRIGORIEV V.Y.2001: Ways and problems of an assessment of antierosion stability of soils. Erosion of soils and river-bedded processes. V. 13. Moscow: Publishing house of the Moscow State University (in Russian).

2. VADYUNINA A.F. KORCHAGINA Z.A. 1973: Methods of Studies of Physical Characteristics of Soils, Moscow (in Russian).

3. VORONIN A.D. 1986: Fundamentals of Soil Physics. Moscow (in Russian).

4. GRIGORIEV V.Y. KUZNETSOV M.S. 1986: Water stability of soil structure as affected by sprinkler irrigation, Pochvovedenie, No 8 (in Russian).

5. GRIGORIEV V.Y., PIECHNIK L., PODSIADEOWSKI S. 1993: Evaluation of erosion-control stability of soils in tractor tracks. Pochvovedeniye, No 2 (in Russian).

6. GRIGORIEV V., PIECHNIK L., PODSIADŁOWSKI S. 1993: Prediction of the beginning of rainfall runoff in tracks of agricultural machinery. Pochvovedeniye, No 12 (in Russian).

7. GRIGORIEV V.Y., PIECHNIK L., PODSIADŁOWSKI S. 1996: Evaluation of runoff and soil erosion in ruts made by agricultural machinery. Eurasian Soil Science, 28 (3), pp. 108-119.

8. KUZNETSOV M.S. 1981: The Resistance of Soils to Erosion. Moscow (in Russian).

9. KUZNETSOV M.S., GLAZUNOV G.P. 2004: Erosion and preservation of soils. Moscow: Publishing house of the Moscow State University (in Russian).
10. KUZNETSOV M.S., GLAZUNOV G.P., GRIGORIEV V.Y. 1986: Methods of Studying Erosion Processes. Moscow (in Russian).

11. KUZNETSOV M.S., GRIGORIEV V.Y., GLAZUNOV G.P., FLESS A.D., SOLOVYEVA O.V. 1988: Resistance of sierozems to erosion under furrow irrigation, Pochvovedenie, No 10 (in Russian).

12. KUZNETSOV M.S., GRIGORIEV V.Y., KHAN K.Y. 1990: Prediction and Control of Soil Erosion under Sprinkler Irrigation. Moscow (in Russian).

Streszczenie: Uproszczona metoda określania odporności gleby na erozje i deflację. Podatność gleby na erozję wodną i wietrzną determinowana jest wieloma czynnikami. Za jeden $\mathrm{z}$ ważniejszych uważa się przy tym stan ilościowy i jakościowy struktury agregatowej wierzchniej warstwy gleby. Celem pracy jest zatem przedstawienie nowej, względnie prostej, metody określania zależności między stanem struktury agregatowej wierzchniej warstwy gleby a podatnością tej gleby na erozję i deflację. Metodę tę oparto o analizę ilościową struktury agregatowej, wykonywaną techniką przesiewania na sucho przez dobrany zestaw sit, zgodnie z procedurą podana wcześniej przez Savinowa. Założono przy tym, iż analiza struktury agregatowej odbywa się bezpośrednio $\mathrm{w}$ warunkach polowych, co pozwala na uniknięcie wpływu transportu próbek na uzyskiwane wyniki przesiewania. Wykonywanie analiz w warunkach polowych jest przy tym szczególnie ważne w przypadku gleb o względnie niskiej wytrzymałości mechanicznej struktury agregatowej, a więc w przypadku piasków gliniastych. Przedstawianą metodę zastosowano $\mathrm{z}$ powodzeniem w badaniach prowadzonych w Stacji Hodowli Roślin Wierzenica, położonej nieopodal Poznania.

\section{MS. received April 2008}

Authors' address:

\section{Stanisław Podsiadłowski}

Instytut Inżynierii Rolniczej

Uniwersytet Przyrodniczy

ul. Wojska Polskiego 50, 60-627 Poznań

Poland

e-mail: stapod@up.poznan.pl 